\title{
ROUSSEAU'S CONCEPTION OF GOVERNMENT IN THE WORK DISCOURSE ON POLITICAL ECONOMY
}

Petar Jakopec

\author{
UDK 1Rousseau, J. J. \\ 005.58 \\ 330.1:32 \\ Original scientific paper \\ https://doi.org/10.32701/dp.22.1.3
}

\section{Introduction}

For Jean-Jacques Rousseau (1712-1778), the government in the Discourse on Political Economy was also the government of public economy, which is primarily focused on the common good of the political community itself. The government should be equally well aligned with the general will of the political community and only then is such a political community legitimate. It should also be pointed out that Rousseau's Discourse on Political Economy is an original and thorough prelude to his major philosophical and political work The Social Contract or Principles of Political Right. However, in order to fully understand Rousseau's work, The Social Contract, his Discourse on Political Economy is often neglected ${ }^{1}$. Therefore, it is the intention of the author to draw attention of the scientific community to the Discourse on Political Economy in which Rousseau already in its rudimentary and original form determined the role of the sovereign and the idea of general will in the political community itself. In addition to his prominent and fundamental philosophical and political concepts, in his Discourse on Political Economy Rousseau also problematizes the understanding of economy and separates family economy from political economy, in other words, particular economy from general economy, which will later affect his conception of the common good and the general will.

* External associate at University North — Varaždin, Croatia, E-mail: petar.jakopec@gmail.com

1 It has been omitted in part because of the popularity of The Social Contract in the history of political philosophy, but primarily because the Discourse on Political Economy does not elaborate in detail on the emergence of the political community, but only indicates some key concepts of Rousseau's political philosophy. See also: Dent, N. 2005. Rousseau. London; New York: Routledge, pp. 78-79. 


\section{The role of public economy}

Rousseau begins his Discourse on Political Economy (Discours sur l'Économie politique $)^{2}$ with a renowned and challenging reflection on the idea of economy and the origin of the term economy. In this sense he points out that »Economy, or CEconomy. (Ethics; Politics.), the word comes from the Greek oĩkos, 'house', and vó ${ }^{\circ}$, 'law', and originally meant only the wise and lawful government of a household for the common good of the whole family. The meaning of the term has since been extended to cover the government of the greater family, which is the state." (Rousseau 1999, 2). Economy in the function of management, and in recent times as a scientific activity, affects the economic condition of the individual as well as the social community, and ultimately has consequences for the entire political community. However, in the Discourse on Political Economy Rousseau recognizes fundamental economic difficulties. Therefore, the very concept of economy, according to Rousseau, eo ipso means the management of domestic economy, but also the management of general economy, that is, political economy of a particular political community.

The crucial thought in Rousseau's Discourse on Political Economy is just management of economic goods according to the principle of the general will of the political community. In this context, Rousseau decisively warns that a distinction must be made between "public economy of which I shall be speaking, and which I call government, from the supreme authority, which I call sovereignty; the distinction is that the latter has the right to legislate, and in certain cases imposes obligations on the nation as a body, while the former has the power only to execute, and can impose obligations solely on private individuals." (Rousseau 1999, 5). It is important to point out that Rousseau distinguishes the general will from the will of all and the particular will. Namely, the particular will is particular and refers to the individuals themselves and their individual interests, which are not of general significance. Furthermore, »the will of all is only the sum of private,

2 Rousseau published both Discourse on Political Economy (Discours sur l'Économie politique) and Discourse on the Origin and Foundations of Inequality among Men (Discours sur l'origine et les fondements de l'inégalité parmi les hommes) in 1755. In the Discourse on Political Economy Rousseau explains his own philosophical and political conception of republicanism, and only in 1762 in the work The Social Contract or Principles of Political Right Rousseau elaborates in detail the republican principle of the political community. It is crucial for clearer understanding of this article to point out that in the Discourse on Political Economy Rousseau determined the first formulations of public economy, the general will, the will of all and the particular will. Unlike the discourse in The Social Contract, in the Discourse on Political Economy Rousseau problematized general postulates of economy, but he made a special contribution to problematizing his own term, public economy, as a representation of general interests of the political community. 
particular wills and conflicting interests, incapable of forming a sole moral body and a republican political community that pursues the common good.« (Raunić 2014, 10). While the general will is directed to the common good of the political community. In other words, „the general will is the result of a social contract and it is focused on caring for the common good of the political community. Therefore, all particular wills of all individuals of the political community are subjected to the very activity of the general will. As a kind of a superior will in the political community, the general will takes precedence over the separate interests and particular wills of individuals.« (Jakopec 2020, 127). A fundamental perception of Rousseau's division of will, into particular, the will of all, and the general will (volonté générale) is necessary for a more concrete and clear understanding of Rousseau's conception of the political community. While speaking of the form of the political community, Rousseau uses a comparison, in short »The body politic, considered as a single entity, may be regarded as a living body organized similarly to that of a man. The sovereign power corresponds to the head; laws and custom are the brain, which controls the nerves, and is the seat of the understanding, the will, and the senses, while the organs of sense are the judges and public officers; commerce, industry, and agriculture are the mouth and stomach, making nourishment available to all; public finance is the blood which economic wisdom, performing the function of the heart, guides throughout the body, distributing life and subsistence; the citizens are the limbs and body that make the whole machine move, live, and work." (Rousseau 1999, 5). Thus, Rousseau's conception of the political community as a living organism represents the vital connection of all state organs into the complete function of the political body, governed by the general will in the capacity of the sovereign. Rousseau »sketched a civic way of life, a plan for the political education of the many, which would make the renewal of the general will our daily task.« (Hulliung 2001, 72).

\subsection{General will in relation to particular will}

On the other hand, while in his Discourse on Political Economy Rousseau speaks of the role of the general will, he claims that » In making the general will the first principle of the public economy and the fundamental rule of government, I have not thought it necessary to examine seriously whether officers of state belong to the people or the people to the officers, or whether in public affairs it is the good of the state or the good of its chiefs that should be considered.« (Rousseau 1999, 8). Government towards the sovereign as the supreme authority in form of the general will is the only justified principle of power. If the government, that is, public economy, is directed to the common good and aligned with the general will of the political community, 
then, according to Rousseau, such a political community is legitimate. In this sense, Rousseau argues that »It would therefore be appropriate to add a further distinction, between the popular and the tyrannical forms of public economy. The first kind is that of every state in which a unity of will and interest reigns between the people and its chiefs; and the second kind necessarily exists everywhere where the government and the people have different interests, and contrary wills as a result.« (Rousseau 1999, 8). In other words, it is necessary to classify Rousseau's conception of different wills in the political community because the general will refers to the common good of the political community, whereas the will of all refers to smaller groups of people, and the particular will is often selfish.

In order not to give preference to the particular will or the will of all, and therefore to neglect the role of the general will, Rousseau finds balance in the idea of law. Namely, »it is to law alone that men owe justice and liberty. This is the salutary means of expressing the will of all, which restores in right the natural equality between men. It is the celestial voice which dictates to every citizen the precepts of public reason, teaching him to act according to the maxims of his own judgement and not to be in contradiction with himself.« (Rousseau 1999, 10). Rousseau's commitment and emphasis on the importance of law becomes the foundation of republicanism as a philosophical and political conception in which, above all, freedom of self-determination and self-legislation is respected. Thus »only a political community which respects the postulates of freedom and equality of a man with another man and recognizes to its members the right to moral autonomy, in which they act for the common good of the whole political community is, according to Rousseau, a truly free political community.« (Jakopec 2020, 133). Rousseau, as a thinker about freedom and the republican political community, which is based on a preoccupation for the res publica, that is, on what concerns public affairs, places all concern for the preservation of the political community in the wisdom of law. Moreover, Rousseau points out that »the power of the laws depends even more on their own wisdom than on the severity of their ministers, and the will of the public gains its greatest weight from the reason which dictated it.« (Rousseau 1999, 10-11). The only solid foundation of the republican political community is in law, which is made according to the principle of the sovereign, that is, the general will. In this sense, the government which manages the public economy belongs in the domain of res publica, so the highest good becomes the framework of Rousseau's economy for the republican political community. Therefore, Rousseau firmly concludes that »just as the first duty of a legislator is to make the laws conform to the general will, the first rule of public economy is that the administration should conform to the laws.« (Rousseau 1999, 11). There is no stable political community without the moral autonomy of individuals, without politi- 
cal laws which apply equally to all members of the political community, and in the end without the government of public economy which is subordinate to the sovereign and revealed in the general will. Therefore, Rousseau's final idea is to equate the interests of a sovereign with the general interests, but also with the general will of the political community. (Gourevitch 1997, 114-115).

\section{The importance of possessing virtue for preserving the entity of the political community}

Rousseau also consciously appeals to the importance of possessing virtue, with the aim of more clearly distinguishing the particular interest of an individual from the general interest of the political community present in public economy. Thus, Rousseau argues that »Every ruler who despises his subjects dishonours himself, since he shows that he has failed to make them worthy of respect. Train them therefore to be men, if it is men that you wish to command; if you want the laws to be obeyed, make sure that they are loved, and that men, in order to do as they ought, need only reflect that there is something which they ought to do. (Rousseau 1999, 13). It is necessary for members of the political community to possess intrinsic norms of honest and virtuous action, in order to fully complement and adjust their particular wills with the general will of the law. Furthermore, Lalović points out that »in order to establish an effective government of law, the great art of governing is to instil an ineradicable voice of duty in the very heart of every citizen. Because the government of law is possible only as the government of virtue.« (Lalović 2006, 105). It is precisely the democratic affirmation of individual freedom of all members of the political community that is the novelty which Rousseau introduces and thus creates a free space to act according to virtue. Thus, the possibility of political participation for all individuals is central to Rousseau's thought and is aligned with Rousseau's idea of the political people as the bearer of supreme authority which articulates the interests of the general will.

The role of virtue is crucial, and in this sense, Rousseau claims the following: »do you want the general will to be carried out? - ensure that every particular will is in accordance with it; and since virtue is nothing other than this conformity of particular wills to the general, make virtue reign, to put the same thing in one word. «(Rousseau 1999, 13). It is crucial that individuals in the political community be virtuous and honest, and above all well and thoroughly educated in Aretaic ethics. Moreover, Rousseau substantiates and builds on his claim about the importance of virtuous individuals in the political community with the following words: »If politicians were less blinded by ambition, they would see how impossible it is that any institu- 
tion, of whatever kind, can function according to the spirit in which it was established, unless it is directed by the law of duty; they would realize that political authority has its main source of power in the citizens' hearts, and that in the maintenance of government nothing can replace public morality." (Rousseau 1999, 14). It is on this line of thought that Rousseau's awareness matures about the fact that the concern for the public cause res publica becomes at the same time the concern of every individual in the political community, whose moral autonomy affects a stable and good government in the function of public economy. Man, as an individual is »free, that is, namely, man's substantial nature; and in the state it is not only not abandoned, but, in fact, it is just being constituted. The freedom of nature, the germ of freedom, is not real; for only the state is the realization of freedom." (Hegel 1979, 184). The full recognition of the individual is achieved only through selflegislation, since the individual gains respect for his personality only in the political community and can accordingly influence political laws.

\subsection{Patriotism in the function of the common good}

As the author of the philosophical and political conception of republicanism, Rousseau emphasizes the essence of love for the homeland, that is, the virtue of patriotism. Therefore, in the Discourse on Political Economy, »public education of citizens in the spirit of patriotism is a fundamental task of public authority which should take over the education of children and turn them into citizens who watch over the fate of the republic as if it was their own.« (Sunajko 2008, 46). The virtue of patriotism in Rousseau's sense is not hypocritical, and Rousseau does not advocate for loyalty and love for the homeland like a hypocrite, but strongly and strictly raises awareness of patriotism as a general will and the people as a sovereign who cares for general political interests and public economy as a just government for the political community. Therefore, »The most effective is the love of country; for as I have said already, every man is virtuous when his particular will conforms in all things to the general will." (Rousseau 1999, 16). For the stability of the political community it is necessary to adjust particular, own interests with interests of general importance and the general will. This is exactly where patriotism is manifested and impersonated because, as Rousseau points out »certainly, the greatest marvels of virtue have been done out of patriotism: a vigorous and pleasurable feeling which joins the power of self-love to virtue in all its beauty, giving it energy without disfiguring it, and so creating the most heroic of all passions." (Rousseau 1999, 16). In order to preserve the stability of the political community, the education of individuals in Aretaic ethics, and especially in the virtue of patriotism, becomes the fundamental Rousseau's agenda of public economy, which in its essence rules on the 
principle of patriotism since it is primordially focused on general interests and the common good of the political community itself.

Rousseau appeals to the educational method of respect among all members of the political community. In other words, Rousseau claims, »respect your fellow citizens and you will earn respect yourselves; respect freedom and your power will increase every day; do not exceed your rights, and soon they will be limitless." (Rousseau 1999, 20). In the role of public economy, as the government for the common good of the political community, it is essential that it has the virtue of patriotism, primarily for the sake of social sensitivity towards each individual in the political community. Namely, »one of the most important things for a government to do, therefore, is to prevent extreme inequality in wealth, not by depriving the rich of their possessions, but by denying everyone the means of accumulating them; and not by building poor-houses but by ensuring that the citizens do not become poor." (Rousseau 1999, 20). Rousseau's final idea is to create, with the help of public economy, an environment in which every person will have equal opportunities for their life, without corruption or injustice. Therefore, Rousseau insists on the necessity of possessing virtue and freedom in order to preserve the stability of the political community. Since »love of country cannot subsist without freedom; nor freedom without virtue; nor virtue without citizens. If you can create citizens you have gained everything, but otherwise all you will have is wretched slaves, beginning with the leaders of the state.« (Rousseau 1999, 21). According to Rousseau, teaching in virtue is inviolable so that individuals in the political community can be fully educated about patriotism and thus eo ipso learn how to distinguish particular interests, which are harmful for the preservation of the political community, from general interests which contribute to the stability of the political community. Rousseau also points out that »it is from the first moment of life that we must learn how to be worthy to live; and since we participate from birth in the rights of citizens, it is at the instant of our birth that the exercise of our duties should begin.«(Rousseau 1999, 22).

\subsection{Public economy in the service of the common good of the political community}

The moral duty of individuals to the political community is the foundation for the just government of the public economy. It is important to point out that the law »ensures legal and political equality, and consequently social and economic equality, and this is in fact the right way to establish a just order. Since equality does not consider equal wealth but equal power, it is the law itself that is the module which should ensure equality of power.« (Brčić Kuljiš 2014, 32). With his conception of the republican political community, 
Rousseau advocates respect for the authority of institutions, in order to create a just order in the political community. In this case, Rousseau claims that »for whenever a lesson is not supported by authority, and precept by example, teaching is fruitless; virtue itself loses its credit in the mouth of a man who does not practise it.« (Rousseau 1999, 23). Thus, the possession of virtue is primarily an intrinsic value which arouses patriotism in the individual and concern for the general interests of the political community. However, in order for the political community to be fully consolidated and established, it is necessary to have good laws which will care about private property. For this reason »it is certain that the right of property is the most sacred of all citizens' rights, and in some respects more important than freedom itself, whether because it is more closely connected with the preservation of life; or because, a man's property being easier to appropriate and harder to defend than his person, the thing that is the more readily taken should be the more respected; or finally because property is the true foundation of civil society and the true pledge of the citizens' fidelity in fulfilling their obligations.«(Rousseau 1999, 25). Ownership binds the individual, so preserving property requires just laws which will protect the individual's property from possible threats.

One of Rousseau's key elaborations on the importance of good governance of public economy is government of finance. Rousseau, therefore, encourages the creation of so-called public funds in which public finances, intended for the economic development of the political community, will accumulate. Moreover, Rousseau points out »once the public fund is set up, the chief officers of the state are its administrators by right, since its administration is a part of government, and a part that is always essential, though not always equally essential. Its influence increases in proportion as the influence of the other resources of government diminishes. (Rousseau 1999, 28). It is precisely the question of progress that is in hands of those in power who gained political trust from members of the political community. For the holder of the power of public economy »from this rule is derived the most important maxim in financial administration, which is to devote much greater care to anticipating needs than to increasing revenue.« (Rousseau 1999, 28).

As an advocate of a rational public economy, it can be established that Rousseau's republican conception of the political community is present not only in the role of the general will that cares for the common good, but also in all forms of the government of public finance. In this context, Rousseau refers to ancient political communities in which he often finds justification and inspiration for his own philosophical and political arguments. Accordingly, Rousseau is convinced that »this great maxim had been firmly established in antiquity that governments then achieved such miracles, doing 
more by their parsimony than ours with all our treasure; which is perhaps the origin of the usual sense of the word economy, since it is commonly understood to mean the wise management of what one has, rather than the means of acquiring what one does not have." (Rousseau 1999, 28). It is the maxim of rational and frugal government of economy of the political community that is Rousseau's motto for a socially equal and just state. The greatest threat to the stability of the political community is the pursuit of wealth and the lack of interest in public political interests. Therefore, »we must remember that the foundation of the social pact is property, and that its first condition is that everyone should be guaranteed the peaceful enjoyment of what he owns. It is true that, by the same treaty, everyone undertakes, at least tacitly, to contribute to public needs." (Rousseau 1999, 32). Since the political community is based on the social contract, and about which Rousseau elaborates in detail in the work The Social Contract or Principles of Political Right, here in the Discourse on Political Economy Rousseau refers to the equivalence of the social contract for each participant and signatory of a social contract who will respect to the same extent the rights of others as well as his own rights. In this sense, adherence to the social contract is a turning point for every subject signatory of the social contract, since individuals only by signing the contract create a stable political order of the political community. Therefore, sthis undertaking cannot damage the fundamental law, and supposing that the contributors accept that the need is obvious, it will be clear that their contributions, in order to be legitimate, must be voluntary, not through individual acts of will, as if it were necessary to have the consent of each citizen, who would provide only as much as he pleased, directly contrary to the spirit of the joint agreement, but through the general will by majority vote, following a proportional tariff which would prevent the imposition being in any way arbitrary.« (Rousseau 1999, 32). Rousseau sees service to the general will in the political community, and especially to the people as sovereign, as patriotism and not as compulsion or imposing and collecting labour taxes, the multiplication of which eventually goes to public funds and economy, under the authority of the common good or property of the political community.

\section{The presence of inequality in civilization}

Rousseau clearly observes that the economic needs of a political community grow proportionally to particular interests of individuals in the political community. Rousseau argues that, »if we were to examine the way in which the needs of the state increase, we should find that it often happens in the same way as with private citizens: less out of real necessity than by the growth of useless desires; and that, in many cases, additional expenses are 
incurred only in order to have a pretext for raising revenue. Thus the state would sometimes benefit by omitting to acquire wealth, and its apparent wealth is at bottom more of a burden than poverty would be." (Rousseau 1999, 30). One of the most common internal threats to the stability of the political community is the allocation of funds for taxes. Since the political community is based on the voluntary signing of a social contract, it is a logical sequence for Rousseau that then the care for the political community also lies in freedom and patriotism. Moreover, the political community whose political order and laws are based on the acquisition of more material goods is already, with its political course, focused on particular and not general interests. Therefore, vital interests for the political community are the virtue of patriotism, which serves the general preservation of the political community, and concern for public economy, that is, a just government, which will not protect the rich and oppress the poor. In this sense, according to Rousseau »contributions that are levied on the population are of two kinds: real, when they are due on things; and personal when they are paid by head. Both kinds are called imposts or subsidies; when the people fixes a sum to pay, the tax is known as a subsidy; when it grants all the revenue from a kind of tax it is an impost. (Rousseau 1999, 33). Making a difference in the acquisition and increase of revenue in form of imposts and subsidies, Rousseau deliberately alludes to the individual corrupted by civilization, and points out that the an individual will first, as a moral member of the political community, seek to gain property from his own work. Therefore, an impost or subsidy in the political community is for Rousseau a necessary evil that encourages the creation of political particular egoism and material plunder and justifies negligence for the affairs of public economy. Increasing »the revenue of public economy is a precondition for eliminating the differences in the political community between rich and poor subjects. If the ruler does not take care of his subjects or members of the political community, over whom he has the power to govern, if he does not care for the common good of the political community, does not diminish the differences between the rich and the poor, and further tries to manipulate his members and diminish the responsibility of government, in that case the political community becomes damaged and is threatened to be disintegrated.« (Jakopec 2020, 155). Accordingly, Rousseau warns about the social inequality that grows rapidly in civilization with the accumulation of property and divides members of the political community into rich and poor. In this sense, Rousseau advocates a civilization which will remind the individual of his natural state in which he was before signing the social contract or entering the political community, the so-called state of the noble savage. Namely, Rousseau "concludes that the historical beginning of inequality was initiated by the institution of property that caused the establishment of the magistrate (ad- 
ministration), which resulted in despotism and thus completed the circle of inequality.« (Sunajko 2008, 42). It is Rousseau's basic intention in the Discourse on Political Economy to explain in more detail the social injustice which arose by the creation of private property and to justify in every way the role and function of public economy which represents the power and interest of the general will of the political community.

\subsection{Rousseau's criticism of civilization as an appeal to equality}

Rousseau's criticism primarily relates to property and social disproportions that arise in the political community simply because of particular interests of individuals in the political community. According to Rousseau, »a third factor that is never included in the calculations, and which ought to come first, is the relationship between the benefits that each person receives from his membership of organized society, which powerfully protects the rich man's immense possessions, while scarcely permitting the poor man the enjoyment of the cottage which he has built with his own hands." (Rousseau 1999, 34). Rousseau's criticism of social and politically unjust economy resulted in republican conception of public economy in the function of the sovereign's reign over public affairs res publica, which ultimately shows and represents the general interests of the political community in order to adjust political and economic interests with the general will. In that economic, philosophical and political sense, Rousseau »believed that commerce and money lead to the excessive enrichment of individuals and the increase in the number of poor and dissatisfied, which causes the ruin of the state as well as the people.« (Sunajko 2008, 46).

In his Discourse on Political Economy Rousseau focuses on the relationship between rich and poor individuals in the political community, that is, he seeks to find a just social, philosophical and political order that will equally respect poor and rich individuals. The greatest difficulty of social inequality lies in the conventional way of thinking about social relationships based on needs. Namely, when comparing the relationship between the rich and the poor in the political community Rousseau points out: "You need me, because I am rich and you are poor; let us therefore make an agreement: I will allow you to have the honour of working for me, on condition that you give me the little that you still have in return for the trouble I take to give you my orders." (Rousseau 1999, 35). Constant competition in as much power as possible is a source of an unjust and unfavourable social contract that can be devastating for the political community. Finally, it should be noted that Rousseau's conception of achieving economic balance is based on equality before law for all members of the political community. 


\section{Conclusion}

In the Discourse on Political Economy Rousseau, as an enlightener, but also as a critic of the Enlightenment, reflects on and discusses the appropriate organization of a political community. In the Discourse, in addition to terms such as the general will or particular will, Rousseau also mentions an enlightenment version of the term sovereign. Since sovereignty signifies the highest or supreme authority, for Rousseau precisely such a sovereign or supreme authority should be in the service of the general will, that is, in hands of public economy entrusted with the government and care for the common good of the political community itself. The general will is the political supreme will which, as a higher instance, first cares for the complete maintenance of the political community, and gives primacy to general interests, and keeps under control the particular interests of individuals. In this sense, the importance of public economy emerges, which has the role of justly distributing and redistributing material means for life and thus establishing equality between all members of the political community based on the rule of law. It is precisely loyalty to the rule of law that is manifested in virtues, and especially in the virtues of patriotism. Namely, patriotism truly signifies a commitment to general interests of a political community, since the centre of Rousseau's conception of contractualism is the concern for the common good. In the Discourse on Political Economy Rousseau already advocates a republican conception of political government, which above all cares for the common good. Finally, it should be noted that Rousseau's Discourse on Political Economy is a kind of amendment to The Social Contract, which already in the first outlines discusses and problematizes Rousseau's basic philosophical and political concepts such as sovereign, government, general will, but also public economy, which Rousseau explained in detail in The Social Contract.

\section{Bibliography}

Brčić Kuljiš M. 2014. Koncepcija pravednosti u filozofiji Jean-Jacquesa Rousseaua. Filozofska istraživanja 34 (1-2): 23-36.

Dent, N. 2005. Rousseau. London; New York: Routledge.

Gourevitch, V. (ed.) 1997. Rousseau: The 'Discourses' and Other Early Political Writings. Cambridge: Cambridge University Press.

Hegel, G. W. F. 1979. Jean-Jacques Rousseau. Politička misao 16 (1): 184-185.

Hulliung, M. 2001. Rousseau, Voltaire, and the Revenge of Pascal, In: The Cambridge Companion to Rousseau, Patrick Riley (ed.), 57-77. New York: Cambridge University Press. 
Jakopec, P. 2020. Liberalizam vs. republikanizam: Locke vs. Rousseau. Zagreb: Naklada Breza.

Lalović, D. 2006. Mogućnosti političkoga. Zagreb: Disput.

Raunić, R. 2014. Rousseauov politički emancipacijski projekt. Filozofska istraživanja 34 (1-2): 5-22.

Rousseau, J.-J. 1999. Discourse on Political Economy and The Social Contract. Oxford; New York: Oxford University Press.

Sunajko, G. 2008. Filozofija politike francuskih enciklopedista i njezin utjecaj na Francusku revoluciju. Studia lexicographica 2 (1): 25-50.

Abstract

\section{ROUSSEAU‘S CONCEPTION OF GOVERNMENT IN THE WORK DISCOURSE ON POLITICAL ECONOMY}

\section{PETAR JAKOPEC}

In this article the author problematizes Rousseau's Discourse on Political Economy and his conception of government in the political community. Rousseau's Discourse on Political Economy was chronologically written seven years before his major work The Social Contract or Principles of Political Right. Regardless of the fact that the Discourse on Political Economy was published earlier, it left a remarkable trace in Rousseau's philosophical opus. In this work, which was published as part of the fifth volume of Encyclopedia of the Enlightenment, Rousseau indicated his direction in political philosophy. This philosophical and political direction began with the Discourse on Political Economy and culminated in the philosophical and political conception of republicanism, elaborated in detail in The Social Contract. In this article the author uses critical analysis and reconstruction to establish Rousseau's fundamental ideas about his political philosophy present in the Discourse on Political Economy, with a focus on observing and studying the role of a sovereign and the public economy in the function of the government by general will within the political community.

Key words: Jean-Jacques Rousseau, Discourse on Political Economy, public economy, government, general will, particular will, sovereign, virtue, political community 